\title{
Originals
}

\section{Normal insulin sensitivity during the phase of glucose intolerance but insulin resistance at the onset of diabetes in the spontaneously diabetic BB rat}

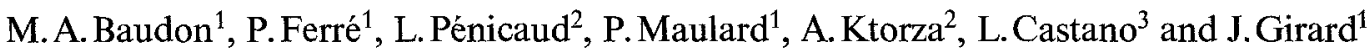 \\ ${ }^{1}$ Centre de Recherches sur la Nutrition, CNRS, Meudon-Bellevue, \\ ${ }^{2}$ Laboratoire de Physiologie du Développement, Université Paris VII, CNRS, and \\ ${ }^{3}$ Unité 188 INSERM, Hôpital St. Vincent-de-Paul, Paris, France
}

Summary. In diabetes-prone BB rats, 30 to $50 \%$ of animals undergo autoimmune destruction of the pancreatic B-cells leading to a short period of glucose intolerance, followed by an abrupt onset of diabetes. We have examined whether the glucose intolerance period and the onset of diabetes are associated with changes in insulin sensitivity, using the euglycaemic hyperinsulinaemic clamp coupled with $\left[3-{ }^{3} \mathrm{H}\right]$ glucose infusion. Glucose intolerant rats were detected by a transient glycosuria one hour after an oral glucose load performed every four days. Insulin sensitivity studied in these rats the day following their detection was normal. Other diabetes-prone BB rats were tested daily and studied on the first day of glycosuria. In the basal state, glucose production was increased in diabetic rats $\left(11.3 \pm 1.1\right.$ vs $7.1 \pm 0.8 \mathrm{mg} \cdot \mathrm{min}^{-1} \cdot \mathrm{kg}^{-1}$, $p<0.05$ ). Tissue glucose utilization was similar in diabetic and control rats $\left(8.3 \pm 0.5\right.$ vs $\left.7.1 \pm 0.8 \mathrm{mg} \cdot \mathrm{min}^{-1} \cdot \mathrm{kg}^{-1}\right)$ despite a three fold higher glycaemia in the diabetic rats. During the hyperinsulinaemic clamps, glycaemia was clamped at 6.1-6.6 mmol/1 in diabetic and control rats. A decreased insulin sensitivity was observed in diabetic rats at submaximal $(200 \mu \mathrm{U} / \mathrm{ml})$ and maximal $(1500 \mu \mathrm{U} / \mathrm{ml})$ insulin concentrations for both inhibition of hepatic glucose production and stimulation of glucose utilization. No autoantibodies against insulin could be detected in the plasma of diabetic rats. Plasma concentrations of glucagon, catecholamines, ketone bodies and fatty acids were similar in control and diabetic rats during the clamp studies. Our results suggest that the decrease of basal insulin concentration is responsible for the insulin resistance in the diabetic BB rat at onset of diabetes, either directly or through the increased glycaemia.

Key words: BB rat, diabetes, glucose intolerance, insulin sensitivity.
Insulin resistance has been largely reported in Type 1 (insulin-dependent) diabetes mellitus, both in newlydiagnosed and in long-standing diabetic patients who have received exogenous insulin therapy $[1,2]$. Longstanding diabetic patients have been exposed to hyperinsulinaemia due to conventional insulin therapy and to long-term metabolic disturbances, both factors which are known to induce a state of insulin resistance [3, 4]. By contrast, newly-diagnosed diabetic patients have been exposed for various time periods to a state of hypoinsulinaemia and its secondary metabolic consequences (hyperglycaemia, hyperlipaemia, hyperketonaemia). The relative roles of insulin lack and that of metabolic disturbances involved in insulin resistance at the onset of Type 1 diabetes in human subjects, are not known. The spontaneously diabetic
BB rat described by Nakhooda and Marliss [5, 6] closely approximates human Type 1 diabetes. In this model, between 60 and 120 days of age, 30 to $50 \%$ of susceptible animals undergo cell-mediated and humoral autoimmune destruction of B-cells and a decreased insulin secretion. Decreasing insulin secretory capacity induces a period of glucose intolerance without basal metabolic disturbances until an abrupt onset of hyperglycaemia with glycosuria [7-9]. The BB rat model, therefore, provides a means to examine whether variations of insulin sensitivity coexist with the relative insulin deficiency during glucose intolerance or with the acute insulinopoenia on the first day of glycosuria, when the diabetic rat has suffered from metabolic disturbances for a very short period of time. 

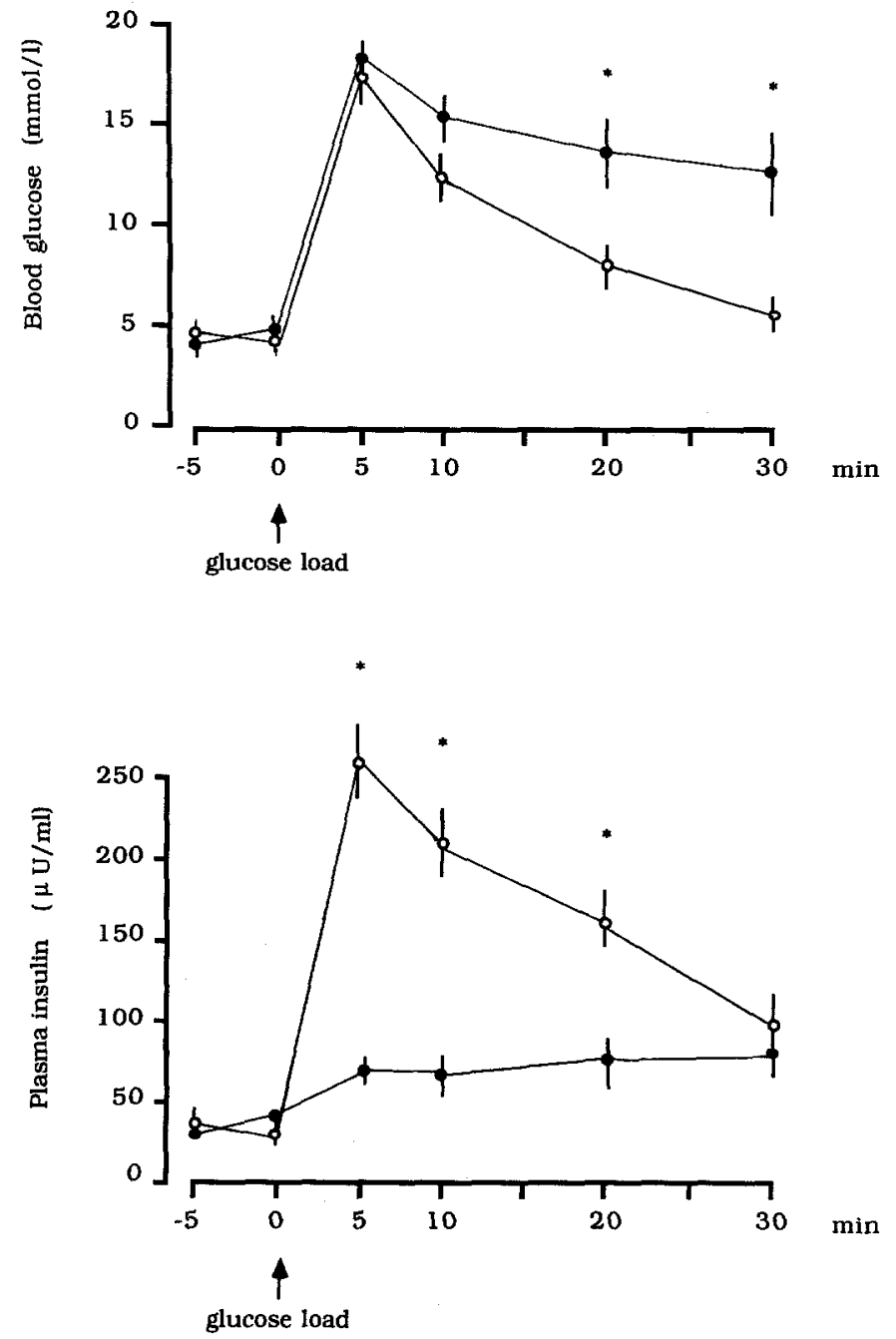

Fig. 1. Blood glucose and plasma insulin concentrations in eight glucose intolerant $(\circlearrowleft)$ and eight control $(O)$ rats during i.v. glucose tolerance tests $(1 \mathrm{mg} / \mathrm{g}$ body weight). Results are means $\pm S E M$. * Difference significant for $p<0.001$ when compared with the control group

\section{Materials and methods}

\section{Animals}

The BB rats were obtained from Dr. P. Thibert (Animal Resources Division, Health protection branch, Ottawa, Canada).

These animals were the offspring of matings between an insulintreated diabetic male and a non-diabetic female known to have produced previous diabetic progeny. The results of all studies were compared with those of age and sex-matched control rats obtained from the same strain but from breeding pairs which have never produced diabetic offspring in a minimum of five sequential litters. Animals were housed in individual cages, fed chow pellets (24\% protein, $4 \%$ fat, $57 \%$ carbohydrate, $6 \%$ cellulose, $9 \%$ minerals, weight/weight) ad libitum, and weighed daily. Temperature, humidity and lighting were strictly controlled.

\section{Time course of metabolic and hormonal disturbances during development of diabetes in $B B$ rats}

In an attempt to characterize the time course of metabolic and/or hormonal disturbances during the development of diabetes, 43 diabetesprone $\mathrm{BB}$ rats, at 70 days of age, were anaesthetised with ether and operated on under clean, but non-sterile, conditions. A bevel-edged silastic catheter (Silastic 602-105, Dow Corning Co, Midland, Mich, USA) was inserted into the jugular vein and pushed to the right atrium of the heart. The catheter was driven subcutaneously to the top of the skull, fixed with cement (Texton, SS White, Paris, France) and occluded with a metal plug following a flush of heparinized $0.9 \% \mathrm{NaCl}$ solution. After recovery of the preoperative body weight (usually, three days), the long-term intracardiac catheter allowed daily blood sampling $(150 \mu \mathrm{l})$ to be performed between 09.00 hours and 10.00 hours in conscious rats in the resting state, for the determination of basal blood glucose, ketone body and plasma insulin concentrations until the first day of glycosuria.

\section{Detection of glucose intolerance in the $B B$ rats}

In a preliminary study, in order to set up a simple and reliable test to detect glucose intolerant rats, an oral glucose tolerance test (OGTT, $3.5 \mathrm{mg} / \mathrm{g}$ body weight) was performed in 20 diabetes-prone BB rats and urine was tested for glucose one $h$ later. The test was repeated every four days and allowed to detect eight rats with a transient glycosuria. These eight rats were anaesthetised the following day with pentobarbital (30 $\mathrm{mg} / \mathrm{kg}$ body weight, i.p.) and underwent an i.v. glucose load ( $1 \mathrm{mg} / \mathrm{g}$ body weight). Eight rats from the same litters which were negative for urinary glucose after the OGTT were used as control animals. Blood was sampled at 5, 10,20 and 30 min after the load, for plasma insulin determination (RIA insulin kit, ORIS Industrie SA, Gif/Yvette, France) and blood glucose measurement (glucose oxidase kit, Boehringer, Mannheim, FRG) after blood deproteinization with 5 volumes of $\mathrm{HCILO}_{4}(6 \%$, weight/volume), centrifugation $(16000 \mathrm{~g}$, $2 \mathrm{~min}$ ) and neutralization. The results are presented in Figure 1 . All the BB rats transiently glycosuric after the OGTT showed a marked glucose intolerance and a decreased insulin secretory capacity when compared to control rats negative for glycosuria (at $5 \mathrm{~min}$, the highest insulin value in the former group was $92 \mu \mathrm{U} / \mathrm{ml}$, whereas the lowest value in the latter was $190 \mu \mathrm{U} / \mathrm{ml}$ ). Using this method, we tested 33 diabetesprone $\mathrm{BB}$ rats every four days.

\section{Detection of diabetic $B B$ rats}

Fifty additional BB rats were monitored daily for body weight and glycosuria at 08.00 hours. These animals later made up the diabetic rat group on their first day of glycosuria.

\section{Glucose turnover rate in the basal state in diabetic rats}

On the first day of glycosuria, at 14.00 hours, and following a $6 \mathrm{~h}$ fast, six diabetic rats and the sex and age-matched control rats were anaesthetised with pentobarbital $(30 \mathrm{mg} / \mathrm{kg}$ body weight i.p.); a tracheotomy was performed and a carotid artery catheterised. The bladder of the diabetic rats was catheterised and emptied. Body temperature was continuously recorded with a telethermometer and carefully maintained at $38^{\circ} \mathrm{C}$ with heating lamps and pads. A tracer dose of $\left[3-{ }^{3} \mathrm{H}\right]$ glucose $(15 \mu \mathrm{Ci}$ [Amersham, Bucks, UK]) in $300 \mu 1$ of heparinized $(100 \mathrm{IU} / \mathrm{ml}) 0.9 \% \mathrm{NaCl}$ was injected as a bolus through a saphenous vein and arterial blood aliquots were sampled at $1,3,5,10$, 20 and then, every $20 \mathrm{~min}$ until $160 \mathrm{~min}$ after the injection.

Blood samples $(50 \mu \mathrm{l})$ were deproteinised with $250 \mu \mathrm{l} \mathrm{ZnSO}_{4}$ $(2.71 \%)$ and $250 \mu \mathrm{l}$ of $\mathrm{Ba}(\mathrm{OH})_{2}(2.62 \%)$ and immediately centrifuged. An aliquot of the supernatant was used for the determination of glucose concentration and another aliquot was evaporated to dryness to remove tritiated water and redissolved in water before counting the radioactivity in a scintillation spectrometer (B-matic, Kontron, France). At the time $160 \mathrm{~min}$, the bladder of the diabetic rats was emptied and an aliquot of urine was treated in the same manner as blood samples for the determination of the amount of $\left[3-{ }^{3} \mathrm{H}\right]$ glucose. At time $160 \mathrm{~min}$, the specific activity of blood glucose was less than $2 \%$ of the 1 min value. The glucose turnover rate $(\mathrm{Rg})$ was calculated as follows: 


$$
\mathrm{Rg}(\mathrm{mg} / \mathrm{min})=\frac{\left[3-{ }^{3} \mathrm{H}\right] \text { glucose injected }(\mathrm{dpm})}{{ }_{0}{ }^{160 \mathrm{~min}} \text { blood glucose specific activity }(\mathrm{dpm} / \mathrm{mg})}
$$

The rate of urinary glucose excretion $(\mathrm{Ru})$ was calculated as follows:

$$
\mathrm{Ru}(\mathrm{mg} / \mathrm{min})=\frac{\text { total urinary }\left[3-{ }^{3} \mathrm{H}\right] \text { glucose }(\mathrm{dpm})}{0 \int^{160 \mathrm{~min}} \text { blood glucose specific activity }(\mathrm{dpm} / \mathrm{mg})}
$$

The rate of glucose utilization by tissues $(\mathrm{mg} / \mathrm{min}$ ) was

glucose turnover rate $(\mathrm{mg} / \mathrm{min})$ - urinary glucose excretion ( $\mathrm{mg} / \mathrm{min})$.

\section{Euglycaemic hyperinsulinaemic clamps in glucose intolerant and diabetic rats}

Using the euglycaemic hyperinsulinaemic clamp technique, insulin sensitivity was studied in eight glucose intolerant rats on the day following the detection of intolerance by OGTT and in 19 diabetic rats on the first day of glycosuria. At 14.00 hours, following a $6 \mathrm{~h}$ fast, animals were anaesthetised and operated on as described previously for the determination of the glucose turnover rate. Euglycaemic hyperinsulinaemic clamps were thus performed in the post-absorptive state [10] as previously described [11]. Briefly, a variable glucose infusion and a constant insulin infusion (Crystalline pork insulin, Novo Industry, Copenhagen, Denmark) were delivered through saphenous veins. In glucose intolerant and control rats, an insulin perfusion rate of $0.4 \mathrm{U} \cdot \mathrm{h}^{-1} \cdot \mathrm{kg}^{-1}$ was used. In diabetic rats and the control animals, two rates of insulin perfusion were used in two different series of experiments: $0.4 \mathrm{U} \cdot \mathrm{h}^{-1} \cdot \mathrm{kg}^{-1}$ (clamp A) and $1.6 \mathrm{U} \cdot \mathrm{h}^{-1} \cdot \mathrm{kg}^{-1}$ (clamp B). Blood glucose concentration was measured every $5 \mathrm{~min}$ on $20 \mu \mathrm{l}$ samples using a glucose analyser (YSI, 23A, Yellow Springs Instrument Co., Yellow Springs, Ohio, USA). Adjustments of the glucose perfusion rate were made to maintain euglycaemia. In diabetic rats, to avoid urinary glucose excretion and to perform the clamps in similar glycaemic and insulinaemic conditions as in control rats, the blood glucose concentration was first allowed to decrease to about 6.1-6.6 mmol/1 and was then maintained at this concentration with variable glucose infusion. A steady-state for both glycaemia and exogenous glucose infusion rate was obtained in $40 \mathrm{~min}$ in both control and glucose intolerant rats and in $60 \mathrm{~min}$ for the diabetic rats. The rate of glucose utilization was determined by a primed continuous infusion of $\left[3{ }^{3} \mathrm{H}\right]$ glucose added to the insulin infusion medium. The priming dose was $20 \mu \mathrm{Ci} / \mathrm{kg}$ and the perfusion rate was $1 \mu \mathrm{Ci}$. $\min { }^{-1} \cdot \mathrm{kg}^{-1}$. Hepatic glucose production was calculated from the difference between the rate of glucose utilization and the rate of exogenous glucose infusion.

Blood samples $(50 \mu \mathrm{l})$ were collected at 20,27 and 35 min after the achievement of the steady state, for the determination of blood glucose specific activity. Blood samples $(500 \mu l)$ were collected before insulin infusion and at the end of the experiment for the determination of non-esterified fatty acids (NEFAC enzymic kit, Biolyon, Dardilly, France), ketone body [12], insulin, pancreatic glucagon (glucagon kit, Serono Diagnostic SA, Coinsins, Switzerland), epinephrine and norepinephrine [13], autoantibodies against insulin [14] and $\mathrm{HbA}_{1 \mathrm{c}}$ (Merckotest Glyc-Hb, Darmstadt, FRG).

\section{Statistical analysis}

Results are presented as means \pm SEM. Statistical significance of differences was assessed by the Student's $t$-test.

\section{Results}

\section{Glucose intolerant rats}

Incidence. Among 33 diabetes-prone $\mathrm{BB}$ rats, 15 were found to be glucose intolerant (i.e.; incidence $=45 \%$ ). The day after detection of their glucose intolerance,
Table 1. Circulating substrate and hormone concentrations, and glucose kinetics in the basal state and during euglycaemic hyperinsulinaemic clamp in postabsorptive anaesthetised control and glucose intolerant rats. Results are means \pm SEM with the number of determi-

\begin{tabular}{|c|c|c|c|c|}
\hline & \multicolumn{2}{|l|}{ Basal state } & \multicolumn{2}{|c|}{ Clamp $(150 \mu \mathrm{U} / \mathrm{ml})$} \\
\hline & $\begin{array}{l}\text { Control } \\
\text { rats } \\
(n=6)\end{array}$ & $\begin{array}{l}\text { Glucose } \\
\text { intolerant } \\
\text { rats } \\
(n=8)\end{array}$ & $\begin{array}{l}\text { Control } \\
\text { rats } \\
(n=6)\end{array}$ & $\begin{array}{l}\text { Glucose } \\
\text { intolerant } \\
\text { rats } \\
(n=8)\end{array}$ \\
\hline $\begin{array}{l}\text { Glucose } \\
(\mathrm{mmol} / \mathrm{l})\end{array}$ & $4.7 \pm 0.2$ & $5.3 \pm 0.2$ & $4.9 \pm 0.2$ & $5.1 \pm 0.1$ \\
\hline $\begin{array}{l}\text { B-hydroxy- } \\
\text { butyrate } \\
\text { (mmol/l) }\end{array}$ & $0.20 \pm 0.04$ & $0.24 \pm 0.10$ & $0.08 \pm 0.06$ & $0.06 \pm 0.07$ \\
\hline $\begin{array}{l}\text { NEFA } \\
(\mathrm{mmol} / \mathrm{l})\end{array}$ & $0.47 \pm 0.06$ & $0.39 \pm 0.07$ & $0.31 \pm 0.05$ & $0.22 \pm 0.03$ \\
\hline Insulin $(\mu \mathrm{U} / \mathrm{ml})$ & $38 \pm 6$ & $42 \pm 4$ & $156 \pm 6$ & $140 \pm 8$ \\
\hline $\begin{array}{l}\text { Glucose } \\
\text { utilization } \\
\left(\mathrm{mg} \cdot \min ^{-1} \cdot \mathrm{kg}^{-1}\right)\end{array}$ & - & - & $15.6 \pm 0.8$ & $16.6 \pm 1.1$ \\
\hline $\begin{array}{l}\text { Glucose } \\
\text { production } \\
\left(\mathrm{mg} \cdot \mathrm{min}^{-1} \cdot \mathrm{kg}^{-1}\right)\end{array}$ & - & - & $0.4 \pm 0.4$ & $1 \pm 0.4$ \\
\hline
\end{tabular}
nations $(n)$

NEFA: non-esterified fatty acids. There was no statistically significant difference between control and glucose intolerant rats whatever the parameter studied

seven rats were diabetic, and the eight remaining glucose intolerant rats had normal basal glycaemia. These eight latter rats and six control rats negative for glycosuria after OGTT were tested by the euglycaemic hyperinsulinaemic clamp technique.

Insulin sensitivity. The concentrations of substrates and hormones in anaesthetised glucose intolerant rats in the basal state are shown in Table 1. Blood glucose and ketone body concentrations, as well as plasma NEFA and insulin concentrations were similar in the two groups. $\mathrm{HbA}_{1 \mathrm{c}}$ was also identical in control $(3.9 \pm 0.2 \%$, $n=6)$ and glucose-intolerant rats $(4.1 \pm 0.4 \%, n=8)$. During the clamp studies and for hyperinsulinaemia of $150 \mu \mathrm{U} / \mathrm{ml}$, ketone body and NEFA concentrations showed a similar decrease in the two groups.

Moreover, in the glucose-intolerant rats, glucose production was inhibited and glucose utilization was stimulated to the same extent as in the control animals (Table 1).

\section{Diabetic rats}

Incidence and time-course of diabetes. Long-term catheterization in 43 diabetes-prone $\mathrm{BB}$ rats allowed us to compare in conscious resting animals the concentration of various circulating substrates and of insulin in control rats and in rats one day before the onset of diabetes. In the future diabetic rats, blood ketone body, plasma NEFA and insulin concentrations remained within the normal range until the detection of glycosuria (Table 2). In some rats, basal blood glucose concentrations were 
Table 2. Circulating substrate and insulin concentrations in postabsorptive control and diabetic rats one day before glycosuria. Blood was sampled in conscious catheterized animals. Results are means \pm SEM with the number of determinations $(n)$

\begin{tabular}{lcc}
\hline & $\begin{array}{l}\text { Control rats } \\
(n=5)\end{array}$ & $\begin{array}{l}\text { Future diabetic rats } \\
\text { one day before glycosuria } \\
(n=5)\end{array}$ \\
\hline $\begin{array}{l}\text { Glucose }(\mathrm{mmol} / \mathrm{l}) \\
\text { B-hydroxybutyrate }\end{array}$ & $6.1 \pm 0.3$ & $7.2 \pm 1$ \\
$(\mathrm{mmol} / \mathrm{l})$ & $0.27 \pm 0.05$ & $0.24 \pm 0.06$ \\
$\mathrm{NEFA}(\mathrm{mmol} / \mathrm{l})$ & $0.50 \pm 0.04$ & $0.48 \pm 0.05$ \\
Insulin $(\mu \mathrm{U} / \mathrm{ml})$ & $30 \pm 4$ & $32 \pm 5$ \\
\hline
\end{tabular}

NEFA: Non-esterified fatty acids. There was no significant statistical difference between control and future diabetic rats whatever the parameter studied

higher than normal one day before the major increase leading to glycosuria (Table 2). The incidence of diabetes among the 93 high risk BB rats was $27 \%$. The age at onset varied from 65 to 120 days with a mean at $91 \pm 4$ days.

Diabetic rats in the basal state. The concentrations of substrates and hormones in anaesthetised diabetic rats on the first day of glycosuria and in control rats are shown in Table 3. Blood glucose and ketone body concentrations were respectively three and two fold higher in the diabetic than in the control rats. Plasma NEFA concentrations in diabetic rats were the same.

Plasma glucagon, epinephrine and norepinephrine concentrations were similar in the two groups (Table 3 ), whereas insulin concentration was lower in diabetic than in control rats. Autoantibodies against insulin which are commonly found in the sera of Type 1 diabetic patients, were undetectable in the diabetic and in the control rats. $\mathrm{HbA}_{1 \mathrm{c}}$ was slightly but significantly higher in the diabetic than in the control rats $(5.5 \pm 0.3 \%, n=10$ vs $4.3 \pm 0.2 \%, n=7, p<0.01)$.

In the basal state, glucose production was increased $(+60 \%)$ in diabetic rats $(11.3 \pm 1.1$ vs $7.1 \pm 0.8 \mathrm{mg}$. $\left.\min ^{-1} \cdot \mathrm{kg}^{-1}, n=6, p<0.05\right)$. However, when the urinary glucose excretion was taken into account, there was no significant difference in the rate of tissue glu- cose utilization in diabetic and control rats $(8.3 \pm 0.5 \mathrm{vs}$ $7.1 \pm 0.8 \mathrm{mg} \cdot \mathrm{min}^{-1} \cdot \mathrm{kg}^{-1}, n=6$ ).

Insulin sensitivity. Insulin sensitivity was assessed by the euglycaemic hyperinsulinaemic clamp at similar blood glucose and plasma insulin concentrations in diabetic and control rats. The two rates of glucose infusion used (clamp A: $0.4 \mathrm{U} \cdot \mathrm{h}^{-1} \cdot \mathrm{kg}^{-1}$ and clamp B: $1.6 \mathrm{U} \cdot \mathrm{h}^{-1}$. $\mathrm{kg}^{-1}$ ) allowed to reach steady-state plasma insulin concentrations (SSPI) similar in diabetic and control rats (clamp A: $200 \mu \mathrm{U} / \mathrm{ml}$; clamp B: $1480 \mu \mathrm{U} / \mathrm{ml}$ ). Substrate and hormone concentrations during clamp $A$ and $B$ are shown in Table 3 . Ketone body concentrations, which were greater in diabetic than in control rats in the basal state were decreased during clamp B and became similar to those of control rats. Plasma NEFA concentrations were slightly decreased during the clamp but remained identical in the two groups.

Despite the decrease in glycaemia induced by insulin in diabetic rats, none of the counterregulatory hormones tested (glucagon, epinephrine, norepinephrine) were increased during the euglycaemic clamp when compared to the basal state.

Glucose utilization and production are presented in Figure 2. For both insulin concentrations $200 \mu \mathrm{U} / \mathrm{ml}$ (clamp A) and $1480 \mu \mathrm{U} / \mathrm{ml}$ (clamp B), glucose utilization was significantly lower $(-30 \%)$ in diabetic than in control rats. Hepatic glucose production was totally suppressed in control rats whereas it was suppressed by only $50 \%$ in diabetic rats.

In three diabetic rats, it was not possible to normalise blood glucose concentration $(13.7,16$ and $18.7 \mathrm{mmol} / \mathrm{l}$ ) during the clamp despite the presence of high plasma insulin concentrations (respectively 356, 250 and $234 \mu \mathrm{U} / \mathrm{ml}$ ). These three values are not included in the means presented in Figure 2.

\section{Discussion}

In human Type 1 diabetes, insulin action is altered both in newly-diagnosed $[1,15]$ or long-standing diabetes $[2$, 16-18] but the mechanism of the development of this

Table 3. Circulating substrate and hormone concentrations in the basal state and during euglycaemic hyperinsulinaemic clamp in postabsorptive anaesthetised control and diabetic rats on first day of glycosuria. Results are means \pm SEM with the number of determinations $(n)$

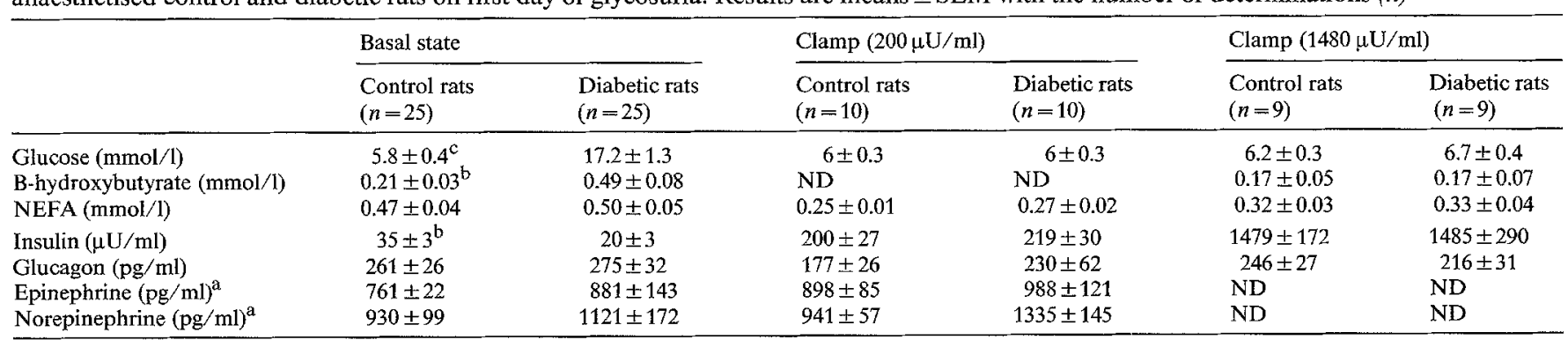

a Epinephrine and norepinephrine concentrations in basal state were determined for $n=10 .^{\mathrm{b}} p<0.05$ and ${ }^{\mathrm{c}} p<0.001$ compared with the control group. NEFA: non-esterified fatty acids; ND: not determined 


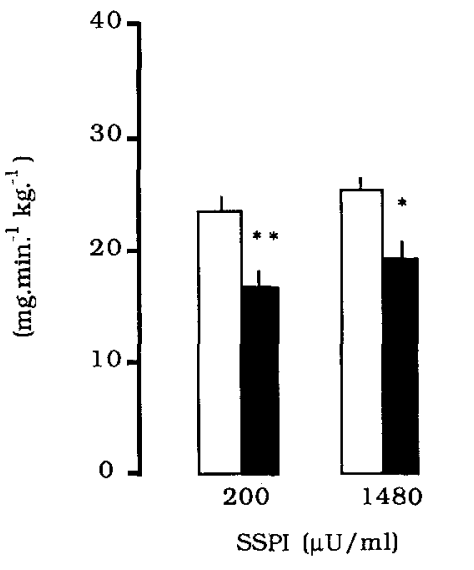

GLUCOSE UTILIZATION

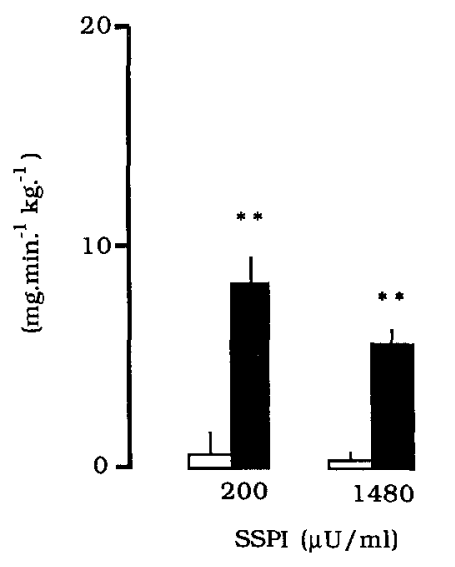

GLUCOSE PRODUCTION
Fig. 2. Glucose utilization and production during the euglycaemic hyperinsulinaemic clamp studies in postabsorptive anaesthetised control $\square$ and diabetic ( rats. SSPI: steady state plasma insulin concentrations. The corresponding glycaemia is indicated in Table 3. Results are means $\pm S E M$. Differences significant for $* p<0.05$ and $* * \quad p<0.001$ when compared with the control group insulin resistance is poorly understood. The BB rat model, in which the time course of metabolic and hormonal environment can be accurately characterized is appropriate to determine the time-course of insulin resistance during the development of diabetes.

In an attempt to follow the appearance of metabolic and hormonal disturbances, diabetes-prone animals have been catheterized on a long-term basis. The surgery, the presence of intracardiac catheter and the daily blood sampling did not induce infection in the BB rats despite their altered immunity [19] and allowed blood sampling without stress or anaesthesia. It confirmed [7] that none of the measured criteria in the post-absorptive state (NEFA, ketone bodies, insulin and glucose concentrations) can be used as a reliable marker of the prediabetic period. Previous studies $[7,8,20]$ and the present work have shown that in spite of this normal metabolic situation in the post-absorptive state, an inadequate insulin secretion in response to glucose appears 1-2 weeks before the onset of diabetes. This implies that the normal meal-induced insulin excursions do not take place during this period. Other physiological situations with continuously low insulin concentrations such as fasting [21] or suckling [22] are accompanied by insulin resistance. The absence of insulin resistance in glucose-intolerant BB rats suggests that a normal insulin concentration in the post-absorptive range is sufficient to maintain a normal insulin sensitivity.

Diabetes in BB rats is characterized on the first day of glycosuria by an increased basal hepatic glucose production which is the consequence of both hypoinsulinaemia and hepatic insulin resistance as shown by the clamp studies. In contrast, in human Type 1 diabetic subjects, a normal insulin suppression of hepatic glucose production was found after a $24 \mathrm{~h}$ withdrawal of the insulin treatment [16]. This experimental condition might have dampened the consequence of insulin deficiency on hepatic insulin sensitivity.

On the first day of glycosuria, a normal basal rate of glucose utilization was achieved in diabetic BB rats in the presence of marked hyperglycaemia, known to in- crease glucose utilization by a mass-action effect. Normalisation of blood glucose concentration during the clamp studies shows insulin resistance of glucose utilization in the diabetic BB rats.

What are the possible causes of this hepatic and peripheral insulin resistance?

During the euglycaemic clamp, plasma glucagon, epinephrine and norepinephrine concentrations in diabetic rats with normalised glycaemia were similar to those found in control rats. This suggests that counterregulatory hormones are probably not involved in the hepatic and peripheral insulin resistance observed in diabetic $\mathrm{BB}$ rats.

Elevated concentrations of plasma NEFA and blood ketone bodies are known to reduce insulin-mediated glucose uptake especially in muscles [23]. Although blood ketone body concentrations were elevated in the basal state in diabetic rats, they reached similar levels in diabetic and control rats during the euglycaemic clamp. Moreover, hyperinsulinaemia decreased plasma NEFA to the same extent in the two groups during the clamp. This suggests that NEFA and ketone bodies could not inhibit glucose utilization in diabetic rats and that the antilipolytic effect of insulin is not altered in diabetic $\mathrm{BB}$ rats.

Insulin resistance could be the consequence of the presence of autoantibodies against insulin. Indeed, insulin autoantibodies are found in 20 to $50 \%$ of newly-diagnosed untreated Type 1 diabetic subjects [24, 25]. Wilkin et al. [26] have found a higher insulin binding capacity in the plasma of diabetes-prone rats when compared to control rats, whereas Dean et al. [27] have found only a weak association between the presence of autoantibodies against insulin and the development of diabetes in BB rats. In accordance with the present study, other authors [28] have found no detectable autoantibodies, strongly suggesting that immunological factors do not counteract insulin action in the diabetic $\mathrm{BB}$ rats at the onset of diabetes.

Hyperglycaemia per se has also been involved in the development of insulin resistance [3]. Indeed, an insulin 
resistant state observed in partially pancreatectomized rats was overcome by correcting the hyperglycaemia with phlorizin [29]. In the glucose intolerant rats, the normal percentage of $\mathrm{HbA}_{1 \mathrm{c}}$ suggests that episodes of meal-induced hyperglycaemia remained very mild. In contrast, on the first day of glycosuria $\mathrm{HbA}_{1 \mathrm{c}}$ was slightly but significantly increased in the diabetic rats $(p<0.01)$. Thus, one cannot exclude a possible role of hyperglycaemia in the development of insulin resistance in diabetic rats.

In summary, in BB rats, insulin sensitivity is normal during the impaired glucose tolerance period preceding diabetes, but a hepatic and peripheral insulin resistance appears at the onset of diabetes. It is then tempting to speculate that the decrease of basal insulin concentration observed during this transition is responsible for the insulin resistance in the diabetic BB rats at the onset of diabetes either directly or through the increased glycaemia.

Acknowledgments. This work was supported by a grant from "Aide aux jeunes diabétiques" to M. A. Baudon and by research grants from INSERM (CRE $\left.n^{\circ} 874004\right)$ and Novo Research Industry, Paris.

\section{References}

1. Nankervis A, Proietto J, Aitken P, Alford F (1984) Impaired insulin action in newly diagnosed Type 1 (insulin-dependent) diabetes mellitus. Diabetologia 27: 497-503

2. De Fronzo RA, Simonson D, Ferrannini E (1982) Hepatic and peripheral insulin resistance: a common feature of Type 2 (non-insulin-dependent) and Type 1 (insulin-dependent) diabetes mellitus. Diabetologia 23: 313-319

3. Yki-Järvinen H, Helve E, Koivisto VA (1987) Hyperglycemia decreases glucose uptake in Type 1 diabetes. Diabetes 36: 892-896

4. Rizza RA, Mandarino LJ, Genest J, Baker BA, Gerich JE (1985) Production of insulin resistance by hyperinsulinaemia in man. Diabetologia 28: 70-75

5. Nakhooda AF, Like AA, Chappel CI, Murray FT, Marliss EB (1977) The spontaneously diabetic Wistar rat. Metabolic and morphologic studies. Diabetes 26: 100-112

6. Marliss EB, Nakhooda AF, Poussier P, Sima AAF (1982) The diabetic syndrome of the $B B$ Wistar rat: possible relevance to Type 1 (insulin-dependent) diabetes in man. Diabetologia 22: 225-232

7. Nakhooda AF, Like AA, Chappel CI, Wei CN, Marliss EB (1978) The spontaneously diabetic Wistar rat (the BB rat). Studies prior to and during development of the overt syndrome. Diabetologia 14: $199-207$

8. Nakhooda AF, Poussier P, Marliss EB (1983) Insulin and glucagon secretion in BB Wistar rats with impaired glucose tolerance. Diabetologia 24: 58-62

9. Tannenbaum GS, Cool E, Wanamaker L, Gurd W, Goldman H, Seemayer TA (1981) Dynamic time-course studies of the spontaneously diabetic BB rat. Insulin-, glucagon-, and somatostatinereactive cells in the pancreas. Endocrinology 109: 1880-1887

10. Smadja C, Morin J, Ferré P, Girard J (1988) Metabolic fate of a gastric load in unrestrained rats bearing a portal vein catheter. Am J Physiol 254: E407-E413

11. Leturque A, Burnol AF, Ferré P, Girard J (1984) Pregnancy-induced insulin resistance in the rat: assessment by glucose clamp technique. Am J Physiol 246: E25-E31
12. Williamson DH, Mellanby J, Krebs HA (1962) Enzymatic determination of $D(-)$-B-hydroxybutyric acid and acetoacetic acid in blood. Biochem J 82: 90-96

13. Sole MJ, Nassir-Hussain M (1977) A simple specific radioenzymatic assay for the simultaneous measurements of picogramme quantities of norepinephrine, epinephrine and dopamine in plasma and tissues. Biochem Med 18: 301-330

14. Palmer J, Asplin CM, Clemons P, Lyen K, Tatpati O, Raghu PK, Paquette TL (1983) Insulin antibodies in insulin dependent diabetics before insulin treatment. Science 222: 1337-1339

15. Yki-Järvinen H, Koivisto VA (1984) Insulin sensitivity in newly diagnosed Type 1 diabetics after ketoacidosis and after three months of insulin therapy. J Clin Endocrinol Metab 59: 371-378

16. De Fronzo RA, Hendler R, Simonson D (1982) Insulin resistance is a prominent feature of insulin-dependent diabetes. Diabetes 31: $795-801$

17. Proietto J, Nankervis A, Aikten P, Caruso G, Alford F (1983) Glucose utilization in Type 1 (insulin-dependent) diabetes: evidence for a defect not reversible by acute elevations of insulin. Diabetologia 25: 331-335

18. Barrett EJ, De Fronzo RA, Bevilacqua S, Ferrannini E (1982) Insulin resistance in diabetic ketoacidosis. Diabetes 31: 923-928

19. Yale JF, Marliss EB (1984) Altered immunity and diabetes in the BB rat. Clin Exp Immunol 57: 1-11

20. Tannenbaum GS, Colle E, Gurd W, Wanamaker L (1981) Dynamic time-course studies of the spontaneously diabetic BB Wistar rat. Longitudinal profiles of plasma growth hormone, insulin, and glucose. Endocrinology 109: 1872-1879

21. Pénicaud L, Kandé J, Le Magnen J, Girard J (1985) Insulin action during fasting and refeeding in rat determined by euglycemic clamp. Am J Physiol 249: E514-E518

22. Issad T, Coupé C, Ferré P, Girard J (1987) Insulin resistance during suckling period in rats. Am J Physiol 253: E142-E148

23. Randle $P$, Garland $P$, Hales $C$, Newsholme E, Denton R, Pogson $C$ (1966) Interactions of metabolism and the physiological role of insulin. Recent Prog Horm Res 22: 1-48

24. Atkinson MA, Maclaren NK, Riley WJ, Fisk DD, Spillar RP (1986) Are insulin autoantibodies markers for insulin-dependent diabetes mellitus? Diabetes 35: 894-898

25. Ludwig SW, Faiman C, Dean HJ (1987) Insulin and insulin receptor autoantibodies in children with newly diagnosed IDDM before insulin therapy. Diabetes 36: 420-425

26. Wilkin T, Kiesel U, Diaz JL, Burkart V, Kolb H (1986) Autoantibodies to insulin as serum markers for autoimmune insulitis. Diabetes Res 3: 173-174

27. Dean BM, Bone AJ, Varey AM, Walker R, Baird JD, Cooke A (1987) Insulin autoantibodies, islet cell surface antibodies and the development of spontaneous diabetes in the BB/Edinburgh rat. Clin Exp Immunol 69: 308-313

28. Markholst H, Laursen HV, Lernmark $\AA$ (1988) Detection of autoantibodies and antibodies against insulin in the BB rat. Diabetes 37 [Suppl 1]: 229

29. Rossetti L, Smith D, Shulman GI, Papachristou D, De Fronzo R (1987) Correction of hyperglycemia with phlorizin normalizes tissue sensitivity to insulin in diabetic rats. J Clin Invest 79 : $1510-1515$

Received: 15 March 1989

and in revised form: 20 July 1989

Dr. P.Ferré

Centre de Recherche sur la Nutrition

CNRS

9, rue Jules Hetzel

F-92190 Meudon-Bellevue

France 